\title{
Fiscale problemen van multinationals in Europa
}

Citation for published version (APA):

Niessen, R. E. C. M. (1990). Fiscale problemen van multinationals in Europa. Gouda Quint. https://doi.org/10.26481/spe.19900614rn

Document status and date:

Published: 14/06/1990

DOI:

10.26481/spe.19900614rn

Document Version:

Publisher's PDF, also known as Version of record

\section{Please check the document version of this publication:}

- A submitted manuscript is the version of the article upon submission and before peer-review. There can be important differences between the submitted version and the official published version of record.

People interested in the research are advised to contact the author for the final version of the publication, or visit the DOI to the publisher's website.

- The final author version and the galley proof are versions of the publication after peer review.

- The final published version features the final layout of the paper including the volume, issue and page numbers.

Link to publication

\footnotetext{
General rights rights.

- You may freely distribute the URL identifying the publication in the public portal. please follow below link for the End User Agreement:

www.umlib.nl/taverne-license

Take down policy

If you believe that this document breaches copyright please contact us at:

repository@maastrichtuniversity.nl

providing details and we will investigate your claim.
}

Copyright and moral rights for the publications made accessible in the public portal are retained by the authors and/or other copyright owners and it is a condition of accessing publications that users recognise and abide by the legal requirements associated with these

- Users may download and print one copy of any publication from the public portal for the purpose of private study or research.

- You may not further distribute the material or use it for any profit-making activity or commercial gain

If the publication is distributed under the terms of Article $25 \mathrm{fa}$ of the Dutch Copyright Act, indicated by the "Taverne" license above, 
Fiscale problemen van

multinationals in Europa 



\section{Fiscale problemen van multinationals in Europa}

Rede

uitgesproken bij de aanvaarding van het ambt van gewoon hoogleraar in het recht, in het bijzonder in het Belastingrecht, aan de Rijksuniversiteit Limburg te Maastricht op donderdag 14 juni 1990 door

Prof. dr. R.E.C.M. Niessen

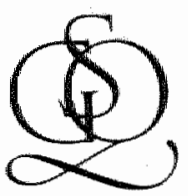

Gouda Quint BV

Arnhem 


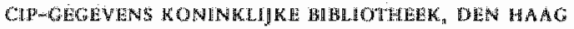

Miessen, R.E.C.M.

Fiscale problemen van multinationals in Europa.

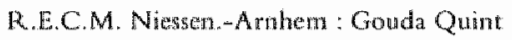

Inaugurele rede Maastricht.

ISBN $90-6000-727-1$

SISO 346.2 UDC $336.2334 .726(4)(043.5)$ NUGI 696

Trew : belastingrecht; Europa.

(C) 1990 Prof.dr, R.E.C.M. Nicsen

Alk rechen voorbehouden. Niets uir deze uiggave mag worden verweelwoudigd, opgeslagen in een gewutonatiseed gegewensbestand, of openbatr gemakt, in enge won of op enige wijze, hetzij clektromisch, mechanisch, door fotocopiezn, opnamen, of enige andere manier, zonder worafgatude schriftelijke toesternming van de uitgever.

Voor zover het maken van kopicen wit deze uitgave is toegestan op grond wan artikel $16 \mathrm{~B}$

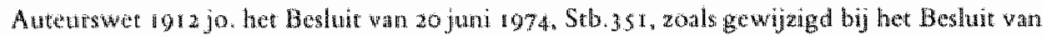

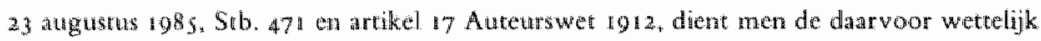
werschuldigde vergoedingen te voldoen aan de Stichting Reprorecht (Postbus: $882.1180 \mathrm{AW}$ Anstelveen). Woor thet overnemen van gedeelte(n) uit deze uitgave in bloenlezingen, readers en andere compilatiewerken (antikel 10 Auteurswet 1912 ) dient men zich to de uitgever to wender. 


\section{Inleiding}

Theorie en praktijk van het belastingrecht worden beheerst door een paradox. Enerzijds wordt de noodzaak een aantal overheidsuitgaven te financieren door middel van algemene heffingen door wrijwel iedereen erkend. Anderzijds koestert eveneens vrijwel iedereen een krachtige aversie tegen het astaan van middelen zonder dat daartegenover een onmiddellijke tegenprestatie staat.

Een belastingwetenschapper zal zich in de regell vooral bezig houden met de eerstgenoemde zijde van deze medaille. Toch bestaat in vrij brede kring het misverstand dat de belastingkundige een dagtaak vindt in het zoeken naar mogelijkheden om belasting te ontgaan. Zo voegde een student mij onlangs toe: " $U$ betaalt zeker geen belasting?' Met andere woorden, een hoogleraar in het bellastingrecht moet wel cen super-ontduiker zijn!

Ook rond het internationale bedrijfsleven hangt een sfeer van nimmer belasting betalen. In deze voordracht zal ik trachten daaraan enige afbreuk te doen door te tonen dat bedrijven soms door twee landen tegelijkertijd worden bellast. Vervolgens zal ik de vraag opwerpen wat de positie van het Europese bedrijfsleven in dic opzicht is en wat daaraan in EG-verband kan worden gedaan.

Er schijnen talloze wegen te leiden naar zonovergoten belastingparadijzen waar het goed toeven is onder de palmen langs ongerepte stranden aan de Stille Oceaan. Niet voor niets mocht het op 24 november 1989 door het Landelijk Overleg Fiscalisten te Groningen georganiseerde Congres over International Tax Planning ${ }^{1}$ zich verheugen in een overstelpende belangstelling. Tijdens dat congres

1. Zic de lustrumbundel Aspecten un international tax planning, nitgave van Stichting Internationa Tax Planning en Nobel Taxmedia DW. Groningen/leiden 1 gido. 
gooide de belastingadviseur W.M. van Dalen nog tlink wat olie op het wuur door in zijn voordracht de zaken aldus voor te stellen alsof in de internationale praktijk elke claim van de fiscus van enig land door listige constructies kan worden teniet gedaan.

Deze voorstelling van zaken dekt een deel wan de werkelijkheid. Belastingplichtigen kunnen aanzienlijke voordelen behalen door handig gebruik te maken van de eigenaardigheden wan verschillende nationale belastingstelsels en de honderden bilaterale verdragen ter voorkoming van dubbele belasting (treaty-shopping). ${ }^{2}$ Er zijn immers talrijke landen die, all dan niet voor bepaalde sectoren, nauwelijks of geen belasting heffen (tax havens). ${ }^{3}$

Gebruikmaking van deze mogelijkheden hoeft geenszins onwettig te zijn. In een aantal gevallen maken belastingplichtigen echter gebruik van de informatievoorsprong die een internationaal concern bezit ten opzichte van de belastingdiensten van de verschillende landen war het concern is gevestigd. Niet ten onrechte heeft D.F. Toornstra in de Doedensbundel betoogd dat er voor de Europese Gemeenschap een taak is weggelegd bij de bestrijding van internationale belastingontwijking. ${ }^{4}$

De EG heeft op dit terrein initiatief ontplooid door middel van de Richtlijn van 19 december 1977 betreffende de wederzijdse bijstand van de bewoegde autoriteiten van de Lid-Staten op het gebied van de directe belastingen. Te onzent is deze Richtlijn uitgevoerd in de Wet op de internationale bijstandverlening bij de heffing wan belastingen (Stb. 1986, 249).

De internationale gemeenschap (al dan niet beperkt tot de EG) zal bij de bestrijding van grensoverschrijdende ontgaansmogelijkheden meer daden moeten stellen dan die Richtlijn," doch in deze voordraclit will ik de andacht vragen voor het tegenovergestelde pro-

2. Zie dienangande bij voorbeeld Deloitte Haskins \& Sells lnternational, Treaty Shopping. K.luwer Deventer 1988

3. Een introductic in deze materie verschaft B.J. Knulse, Belastingparadigen, Khwer Antwerpen 1984.

4. De Europease Gemenschap, dubienze belastingpraktijken en politici, int: Tolvrije gedachren, Kluwer Deventer 1980.

5. A.M.M. Daniels, De grensoverschrijdende gegewensuitwisseling door belastingadministraties, Fiscalc brochures FED, Diversen 6, FED Deventer 1987.

6. Zie OECD-rappore fnternational tax avoidance and evasion ( 1987 ). 
bleem, nl. dat van de nog onvolledige voorkoming van internationale dubbele belasting.

De aandacht van de belasting wetgever beweegt zich heen en weer tussen twee polen. Nu eens let hij op de belangen van de belastingplichtige bij een genuanceerde regelgeving. Dan weer valt zijn oog op de noodzaak paal en perk te stellen aan oneigenlijk gebruik en fraude, en dreigt zelfs de rechtsbescherming te worden verwarloosd. $^{7}$

Met de Europese wetgever is het niet anders gesteld. Terwijl de EEG in oorsprong toch vooral zag op de bevordering van het vrije verkeer tussen de aangesloten landen, dreigt de aandacht zich ten aanzien van de directe belastingen te beperken tot de bestrijding van belastingontduiking.

\section{Voorkoming van dubbele belasting}

Het vraagstuk waarop het internationale belastingrecht zich primair richt, is dat van de voorkoming van internationale dubbele belasting.

Vereenvoudigd voorgesteld laat het probleem zich als volgt omschrijven. Een belastingplichtige $\mathrm{X}$ is gevestigd in land $\mathrm{A}$ clat hem belast voor alle inkomsten die hij geniet ongeacht uit welk deel van de wereld hij deze ook verkrijgt. Een deel van die inkomsten is verworven door middel van bronnen, zoals een dienstbetrekking of onroerend goed, die zijn verbonden met het territoir van land $B$. Dat land belast $\mathrm{X}$ eveneens, $\mathrm{nl}$. voor zover $\mathrm{X}$ inkomen verwerft uit de binnenlandse bronnen van land $B$.

Het is duidelijk dat hier dubbele belastingheffing optreedt ten gevolge van de samenloop van de onbeperkte belastingplicht als binnenlands belastingplichtige in land $\mathrm{A}$ en de beperkte belastingplicht als buitenlands belastingplichtige in land $B .{ }^{B}$

Een dergelijke samenloop wordt algemeen als onwenselijk be-

7. A.M. Domer, Ch.P.A. Geppart en H.J. Hofstra, Herziening administraticue boeten en bevocgdheid tot navorderem. Weekblad voor fiscall redt $1980 / 5867$.

8. Inleidingen in deze materic kan men onder neer anurefen in $\mathrm{C}$. van Redad, Internutional belastingrecht, onderdeel van de losbladige Cursus Belastingrecht (red.: H. Mobach, L. W. Sillevis en N.H. de Vries\}. Gouda Quint Arnhem: alsmedie M. Romijn, International belastingreche in Nederland (eigen ütgawe), tweededruk $198 \%$. 
oordecld. Er zijn dan ook maatregelen genomen om het optreden van internationale dubbele belastingheffing tegen te gaan. In een aantal landen, waronder Nederland, bestaan nationale ("eenzijdi$\left.\mathrm{ge}^{3}\right)$ regels ter beperking van de belastingheffing over buitenlandse inkomensbestanddelen van de ingezetenen.

De voomaamste bron van intemationaal belastingrecht wordt echter gevormd door de vele bilaterale verdragen ter voorkoming van dubbele belasting. Krachtens deze verdragen zien de betrokken landen af van een deel van de frscale aanspraken die zij ingevolge hun nationale wetgeving hebben. Multilaterale verdragen bestaan nauwelijks en zijn van onvoldoende belang om hier te worden vermeld. Wel is als leidraad bij de totstandkoming van de bilateralle verdragen van groot belang het OESO-Modelverdrag waaraan evenwel geen rechtstreekse juridische betekenis toekomt. ${ }^{10}$ Doch mede als gevolg van het bestaan van het OESO-Modelverdrag kennen zeer veel verdragen wel ondering overeenkomende regelingen en verwante begrippen. Bellastingverdragen voorzien overigens niet in alle voorkomende gevallen in de eliminatie van dubbele heffing.

Zo zijn er genoeg bilaterale relaties waarin geen verdrag ter voorkoming van dubbele belasting is gesloten. Verder bevatten de verdragen lang niet altijd voorzieningen voor alle soorten van dubbele belasting die denkbaar zijn. Er is bij voorbeeld vaak geen regeling getroffen ter verhindering van dubbele heffing van successierechten. En ten slotte neemt een verdrag ook ten aanzien van de wel in het oog gevatte samenloop wan heffingen de cumulatie niet altijd geheel weg. Zulks doet zich onder meer voor doordat de in het ene land ten aanzien van een bepaald inkomensbestanddeel geheven bronbelasting weliswaar wordt verminderd doch dat het restant niet kan worden verrekend met de in het woonland verschuldigde belasting."

Bij dit type problemen wil ik hier niet lang blijven stilstaan. Men

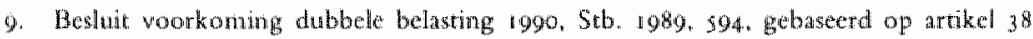
AWR: zit M.R. Reuvers, FED 1990/183.

10. Door de Raad van de OESO werd in $1963 \mathrm{cen}$ Modelverdrag goedgekeurden in $1977 \mathrm{een}$ herziene versio daarvan. De teksten en officiele Commentaren darop zija opgenomen in decl III.D. war Nederlandse regelingen van international belastingreche (losbladig). Kluwer Dewerniter.

11. Bij voorbeeld Duitse bronbelasting op rente betaald aan een Nederlands ingezeterte. 
zou zich kunnen afvragen of hier niet ook een tak is weggelegd woor de Verenigde Naties. Eerdere initiatieven op dit terrein zijn echter gestrand. ${ }^{12}$

Ik wil mij in deze voordracht richten op die situaties die wel in verdragen zijn geregeld, en wel betreffende de heffing van winstbelasting. De vraag is of het bestaan van de verdragsregeling garandeert dat de belastingplichtige verschoond blijft van dubbele belastingheffing. Teneinde deze vraag te beantwoorden zal ik kort ingaan op enkele in belastingverdragen veel voorkomende begrippen en bepalingen, namelijk inzake vestigingsplaats, vaste inrichting en intercompany-pricing.

\section{Vestigingsplaats}

Het eerste vraagpunt waarmee een international opererend bedrijf wordt geconfronteerd, is dat van zijn plaats van vestiging. In het land waar de belastingplichtige is gevestigd, zal hij in de regel worden belast naar zijn wereldinkomen (onbeperkte belastingplicht). De nationale wetgeving van de verschillende landen hanteert echter uiteenlopende aanknopingspunten voor de bepaling van de onbeperkte belastingplicht van vennootschappen. Brood noemt in zijn dissertatie: ${ }^{13}$

- de plaats van oprichting (US, Canada, Nederland, Italië, UK);

- de statutaire vestigingsplaats (Duitsland, Zwitserland);

- de omstandigheden (Nederland);

- management and control (Verenigd Koninkrijk/Canada);

- voornaamste inrichting of bestuur (Belgiê);

- Geschäftsleitung (Duitsland);

- hoofdactiviteit (Italie);

- day-to-day-management (Zwitserland).

In ons rechtsstelsel worden lichamen op twee gronden binnenlands belastingplichtige voor de vennootschapsbelasting. Allereerst door

12. Zie het historisch owerzicht wan J.H. Christianse, in: On der schatinge wille, Kluwer Deventer $z j$, , blz. $168 \mathrm{c}, \mathrm{w}$.

13. E.A. Brood, De westigingsplats van wennootschapper, Fiseale monografienr, 48 , Kluwer Deventer $1989, b 1 z, 23 y-334$. Frankrijk heeft een afwijkend systeem van heffing dat uirgate van de cerritorialitent en dus niet de wereld winst (blz. 1988). 
het enkele feit van oprichting naar Nederlands recht (artikel 2 lid 4 Wet Vpb. 1969). Daamaast geldt de algemene regel dat de vestigingsplats van een lichaam wordt beoordeeld "naar de omstandigheden" (artikel 4 lid I AWR). In de Nederlandse rechtspraak geldt voor wat dit betreft, zoals Verburg het uitdrukt (Conclusie Openbatar Ministerie bij HR 27 april $1988, B N B$ I988/I 81 ) 'het primaat van de plaats van de werkelijke leiding: ${ }^{2}{ }^{14}$

Reeds hieruit blijkt dat het zeer wel kan gebeuren dat een vennootschap volgens het recht van twee landen in ell van die landen is gevestigd, bij voorbeeld een Nederlandse BV warvan de feitelijke leiding in land $\mathrm{X}$ wordt gevoerd. Een dubbele vestigingsplaats is ook in verdragssituaties denkbaar, aangezien verdragen zich ten alanzien van de plats van vestiging vaak refereren aan de nationale wetgeving (vergelijk artikel 4 I OESO-Modelverdrag ${ }^{15}$ ). Als gevolg daarvan is denkbaar dat geen van beide landen bereid is daar terug te treden waar het gepast is voor het land van niet-vestiging. ${ }^{16}$

Nu treedt in dat geval in verdragen die het OESO-Model volgen, artikel $4 \$ 3$ in werking dat als vestigingsland van het lichaam aanwijst the State in which its place of effective management is situated'. Op deze wijze wordt het vraagstuk dichter bij een oplossing gebracht, doch het staat ook dan nog niet vast dat de plaats van 'effective management' in beide landen gelijk wordt beoordeeld. ${ }^{17}$ Integendeel, het begrip 'leiding' is vaag en voor meer dan één witleg vatbaar. ${ }^{18}$

Zelfs al wordt in een dergelijk geval voor de verdragstoepassing de

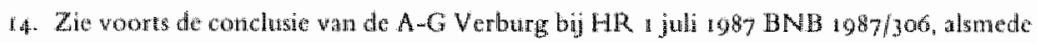

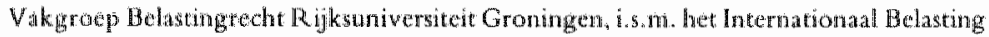

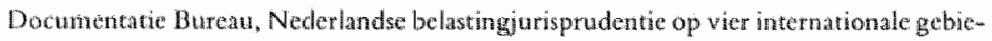
dera, Howfosthe 1 .

15. Cetste volutin: "For the purposes of this Convention, the rem "resident of a Contracting State" menas any person who, under the laws of that state is liable to eax tharein by rascon of his domicile, residence, place of management on any other citerion of a similat nature".

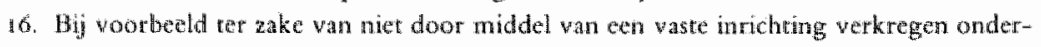
nemingstaten De dubbele vertigingsplats wordt overigh ook wel gebrukrals middel tot belatingontwiking.

17. Brood, a. wi, bliz, 243 .

18. Brood, a. w, blz. 236 ev, vergelijk Wan Brunschot, noot BNB 1980/87. Het Modelwerdrag ken voor lichamen nier ear catalogus van elkar opvolgende criteria zoals in artikel 4 
kwestie van de vestigingsplaats op bevredigende wrijze opgelost, dan nog geld dat resultaat niet ten aanzien van de niet door het verdrag gedekte gevallen. Zo kan de belastingplichtige uit een derde land $C$ baten verkrijgen warop beide landen een fiscale claim doen gelden met toepassing van het wereldwinstprincipe.

\section{Vaste inrichting}

De volgende bron van onzekerheid wordt gevormd door het begrip 'vaste inrichting'. Dit begrip vormt in het intemationale belastingrecht het criterium voor de vraag of de acriviteiten die een in land $A$ gevestigde belastingplichtige uitoefent in land $B$, in het eerst- dan wel het latstgenoemde land mogen worden belast. Indien sprake is wan een vaste inrichting, mag land $B$ de daarmede behaalde winst belasten, en moet land A een vrijstelling verlenen. Indien de activiteiten niet de vorm van een vaste inrichting aannemen, geldt het omgekeerde.

Artikel $5 \$ \mathrm{I}$, OESO-Modelverdrag geeft de volgende definitie van dit begrip; "Voor de toepassing van deze overeenkomst betekent de uitdrukking "vaste inrichting" een vaste bedrjfsinrichting warin de werkzaamheden van de onderneming geheel of gedeeltelijk worden uitgeoefend'.

Hund $^{19}$ noemt deze definitie "een weinig zeggend criterium" (blz. I 17 ). Artikel $5 \$ 2$ beoogt enige verduidelijking te bieden door enkele verschijningsvormen te noemen die in elk geval een vaste inrichting opleveren. In de Nederlandse vertaling: 'een plaats waar leiding wordt gegeven, een filiaal, een kantoor, een fabriek, een werkplaats, en een mijn, een olie- of gasbron, een steengroeve of een andere plats waar natuurlijke rijkdommen worden gewonnen". Weliswar verkrijgt de lezer op deze wijze een algemene indruk van wat met "vaste inrichting' wordt bedoeld, doch wanneer men de aandacht richt op concrete gevallen, dan blijkt toch heel veel rumte anwezig "voor verschillende interpretatie' (Hund, t.a.p.).

$\$ 2$ opgenomen ter waststelling van de woonplats van naturilijke personen. Zie voorts Canters de drote fiscale incernational, Volume LXXII a, The fuscal residence of companies, Kluwer Deventer $198 \%$.

19. D. Hund, Belastingverdragen, Kluwer/Fenedex, Deventer/'s-Graverihage, 24 druk 1983 . 
Uit de toelichting bij het Modelverdrag blijkt dat de opstellers daarvan "hebben getracht het essentiele kenmerk van de vaste inrichting, te weten dat de inrichting een duidelijke "situs" heeft, tot witdrukking te brengen in de woorden "fixed place of business". Voor het overige is het commentaar buitengewoon zwijgzam over de betekenis van de in de abstracte definitie gebruikte termen. Aangenomen moet worden, dat het de bedoeling van de opstellers was, dat er uit de praktjk van de verdragstoepassing cen nadere concretisering van de begrippen "place of business", "fixed" etcetera zou voortvloeien". ${ }^{20}$

Mogelijkheden te over dus voor uiteenlopende rechtstoepassing in verschillende landen. In dit verband is het interessant om bij Nooteboom en Bouwman te lezen dat een vaste inrichting volgens de Nederlandse rechtspraak noch "vast" behoeft te zijn, noch een "inrichling" hoeft te behelizen. ${ }^{21}$

\section{VI-Winst}

Wanneer eenmaal vaststaat dat een vaste inrichting aanwezig is, is het leed nog geenszins geleden. In de regel zal de winst van de vaste inrichting worden bepaald onder thantering van de fictie dat de vaste inrichting een zelfstandige onderneming is (artikel 792 , OESOmodel). Toch ontstaan reeds hier problemen, onder meer in de relatie met een aantal staten in de USA die het systeem van de zogenaamde 'unitary taxation' hanteren, waarbij de winst aan landen wordt toegerekend naar gelang van een verdeelsleutel die is gebaseerd op een combinatie van de factoren loonkosten, omzet en vermogen. ${ }^{22}$

De toepassing van de zelfstandigheidsfictie of methode van onderw nemingssplitsing is evenwel zelf ook verre van eenduidig. Vragen die hierbij moeten worden beantwoord, zijn onder andere: welke vermogensbestanddelen worden toegerekend aan de vaste inrichting en

20. Q.J. van Leywhors, De vate inrichting/vaste vertegenwoordiger, in: Neder andse

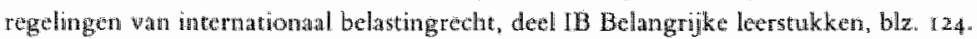

2. A. Nooteboom an J. W. Bouwman, Wegwijs in de vennootschapbelasting, Koninklijke Vertuninde, Lelystad 1989, ble, 92.

2. Charles E. MeLure, JP., Economic integration and European taxation of corporate ineome at soure: some bestons from the US experience, European Taxation $1989 / 8$. 
welke ondernemingskosten drukken op het vaste-inrichtingsresultaat? $?^{23}$.

Ik zal iets yan de vraagstukken waarmee de praktjk op dit gebied. wordt geconfronteerd, tonen aan de hand van enige Nederlandse rechtspraak. De Hoge Raad huldigde in het verlleden een, in de literatuur overigens nogal bekritiseerde, opvatting die wordt aangeduid als 'de leer van het gedeelte'. In deze leer wordt benadrukt 'dat de vaste inrichting, hoewel gefingeerd zelfstandig, juridisch toch een onderdeel vormt van de grotere, generale onderneming. Om die reden mag in deze opvatting bij de winstbepaling vasn de vaste inrichting geen rekening worden gehouden met zogenaamde interne transacties; dat zijn transacties waarbij de vaste inrichting als fictief zelfstandige partij handelt met de generale onderneming' ${ }^{24}$

Een toepassing van deze leer kan men aantreffen in $H R$ i 2 februari 1964, BNB 1964/95, het vermaarde hopperzuigerarrest. Het arrest had betrekking op een geval waarin een Nederlands bedrijf een bedrijfsmiddel tijdelijk ten gebruike had afgestaan aan zijn buitenlandse vaste inrichting. De Hoge Raad oordeelde dat woor de berekening van de vaste-inrichtingswinst mocht worden uitgegaan van de boekwaarde van dat bedrijfsmiddel op de generale balans, en derhalve niet van de waarde in het economische verkeer van dat bedrijfsmiddel bij inbreng in het vermogen van de vaste inrichting. Wanneer de boek waarde van het bedrijfsmiddel roo was en de waarde in het economische verkeer 250 , dan diende derhalve bij de berekening van de VI-winst een afschrijvingsbasis wan 100 in aanmerking te worden genomen. De rellatief lage afschrijving leidde tot een hoge VI-winst en dus resulteerde een hoge vrijstelling. ${ }^{25}$

Wanneer op deze wijze de vaste-inrichtingswinst van een butenlandse belastingplichtige in Nederland wordt berekend, terwijl in het andere land wordt uitgegaan van een verhoogde afschrijvingsgrondslag, is dubbele belastinghefing het gevolg.

Aangezien men in het duister tast omtrent de reikwijdte van dit

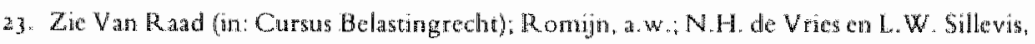
Cursus Belastingrecht (Vennootschapsbelasting), onderdeel 3.0.2.

24. C. van Rad, Beweeglikheid in het international belastingreche, Oratie Leiden 28 april 1987, Kluwer Deventer 1987, bl2. 6-7.

25. Hiertegen keert zich artikel 2 lid 4 Besluit voorkoming dubbele belasting 198 . Aangenomen wordt dat het arrest wel toepassing windt in verdragssituaties. 
arrest, zijn de fuscale gevolgen van allerle belangriyke en veel voorkomende handelingen woor bedrijven met een vestiging in Nederland onzeker. Ellis somt onder andere de volgende gevallen op:

1. overdracht van bedrifsmiddelen van hoofdkantoor naar vaste inichting in sen verdragsland;

11. overdracht van bedrifsmiddelen van een waste inrichting in het ene land naar een vaste inrichting in een ander land of naar het hoofdantoor;

II. emigratie van de belastingplichrige zonder staking van zun onderneming in Nederland.

Zelfs heeft de meest recente rechtspraak (HR 4 juni 1986, BNB 1986/230, HR \& nowember $1989, \mathrm{BNB}$ r990/36/nog geen zekerheid verschaft over de wrag of de Hoge Raad de leet van het gedeelte heeft verlaten ${ }^{27}$

In hoeverre ten aanzien van deze problemen de belastingverdragen uitkomst bieden, is minst genomen onzeker. ${ }^{28}$

De slotsom van $V$ an $R$ aad is dat door de verschillen tussen de fiscale winstbepalingsregels van de diverse staten de winst die de bronstaat belast in theorie zelden exact gelijk zal zijn aan de winst waarvoor de woonstaat voorkoming dubbele belasting geeft. ${ }^{29}$

\section{Intercompany-pricing}

Aan de borreltafel wordt gemakkelik ervan uitgegaan dat een international opererend concern door manipulatie met zin interne verrekenprijzen de winst moeiteloos daar kan laten neerslaan waar het belastingtarief het laagst is.

Welnu, rechtens en ook in de praktijk is dat lang niet altijd eenvoudig.

26. Cahiers de droit fiscal international, Volume LXXXIa, Transfer of assets into and ont of at taxing jurisdiction, Kluwer Deventer $1986, \mathrm{blz}, 4$ \$0.

27. Zie woorts Conclusie A-G Verburg bij HR BNB 1990/36.

28. Tann Kergall, Cahiers LXXIa (General report), bla. $\varsigma 6$.

29. Cursus Bellastingrecht (Internationalal belastingredot), 2.5.2. A. 
Veel landen ${ }^{30}$ kennen bijzondere voorzieningen in hun nationale wetgeving teneinde dergelijke manipulaties voor de fiscale winstbepaling terzijde te stellen. Een en ander leidt tot het vraagstuk van de fiscale behandeling van de zogenaamde 'intercompany-pricing".

De bedoelde regelingen houden alle in een of andere vorm in dat de belastingadministratie in geval van transacties tussen partijen die niet onafhankelijk tegenover elkaar staan, kan toetsen of de prijs waartegen is gehandeld, zakelijk verantwoord is. Deze praktijk wordt in veel verdragen gesanctioneerd. Zo schrijft artikel 9 OESOModelverdrag ${ }^{31}$ voor dat in een geval van een correctie in het ene land een tegenovergestelde correctie in het andere land dient plaats te vinden.

Bij de toepassing wan deze regels staan twee vraagstukken centraal:

- wanneer is sprake van gelieerde ondernemingen?

- welke prijs is zakelijk?

Ten aanzien van beide vragen bestaat bepaald geen eenduidig antwoord. Alhoewel de criteria betreffende de mate van gelieerdheid tussen ondernemingen internationaal een zekere mate van over-

30. Onder andere de Bondsrepubliek Duirsland, Frankrijk en de Verenigde Statern van Amerika, zie L.A. Verdoner, Fiscale aspecten wan incercompany-pricing in international verband, Fiscale Monografie m. 47. Kluwer Deventer 198.8.

3.1. Article 9 Associated Enterprises

Where $a$ an enterprise of a Contracting State participates directly or indirectly in the management, control or capital of an enterprise of the other Contracting State, or $b$. the same persons participate directly or indirectly in the management, control or capital of an enterprise of a Contracting State and an enterprise of the other Contracting State, and in either case conditions are made or imposed between the two enterprises in their commercial or financial relations which differ from those which would be made between independent enterprises, then any profits which would "but for those conditions, have accrued to one of the enterprises, but, by reason of those conditions, have not so accrued. may be included in the profits of that enterprise and laxed accordingly.

2. Where a Contracting State includes in the profits of an enterprise of that State-and taxes accordingly - profits on which an enterprise of the other Contracting State has been charged to tax in that other State and the profits so included are profits which would have acerwed to the enterprise of the first-mentioned State if the conditions made berween the two enterprises thad been those which would have been nade between independent enterprises, then that other State shall make an appropriate adjustment to the amount of the tax charged therein on those profits. In determining such adjustment "due regard shall be had to the other provisions of this Convention and the competent authorities of the Contracting States shall if necessary consult each other. 
censtemming vertonen, kan, aldus Verdoner, van eenstemmigheid bepald niet worden gesproken. ${ }^{32}$

In de Amerikanse wetgeving (Section 482 Internal Revenue Code) wordt gewangd van 'organizations, trades or business owned or controlled directly or indirectly by the same interests'. Het begrip "control" wordt hier niet uitgelegd naar gelang van louter de aandeelhouderstelatie, doch op basis van alle in aanmerking komende feiten en omstandigheden.

In het Verenigd Koninkrijk daarentegen stat wel de juridische zeggenschap centraal.

9 I van het Duitse Aussensteucrgesetz stat winstreacties toe in geval van internationale transacties tussen de belastingplichtige en een 'ihm nastehende Person'. Uiteraard ziet dit begrip allereerst op aandeelhouderstelaties waarbij naar Duits recht volstat een 'wesentliche Beteiligung", dat is $25 \%$. Doch voorts strekt de onderhavige regel zich uit tot het geval "wenn die Person oder der Steuerpflichtige imstande ist, bei der Vereinbarung der Bedingungen einer Geschäftsbeziehung auf den Steuerptichtigen oder die Person einen ausserhalb dieser Geschäftsbezichung begründeten Einfluss auszuüben oder wenn einer won ihnen ein eigenes Interesse an der Erziehung der Einkünfte des anderen hat'. In Nederland op zijn beurt is daarentegen in het geheel geen plats voor winstcorrecties op grond van louter een gemeenschappelijk belang tussen de betrokken handelspartners. ${ }^{33}$

Het OESO-Modelverdrag en de toelichting daarbij geven weinig houvast voor de interpretatie van het begrip gelicerd. De Hosson, r.a.p. blz. 1508-I509, merkt op: "Vooral het begrip "control" zal belangrijke problemen kunnen veroorzaken (...). Een belangrijke taak bij en herziening van het OESO-Modelverdrag zou dan ook dienen te liggen in de opname van een definitie wan het begrip "controll" in het verdrag zelf.

Ten aanzien wan de regels voor interconpany-pricing geldt dat deze van tamelijk recente datum zijn. In Nederland kennen wij tot op dit moment geen geschreven wetrelijke regels. Well is er jurisprudentie ${ }^{34}$

32. A.W., biz. 23,

33. Een en ander ortleend as F.C. de Hosson, Het begrip 'gelieerde ondernemingen' in het notionale en internationale belastingrecht, Weekblat voor fiscas reche $1987 / 5799-580 \mathrm{r}$.

34. Vakgroep Belastingrecht Groningen, a, w. Hoofdseuk IV. N.H. de Vries en L. W. Sillevis, 
die is gebaseerd op het algemene principe dat de winst niet mag worden beinvloed door onzakelijke transacties met aandeelhouders en andere kapitaalverstrekkers (artikel ro Wet Vpb. ro6g en artikel 7 Wet IB I964). ${ }^{35}$ Enkele jaren geleden is op een deelgebied wel een resolutie uitgevaardigd. ${ }^{36}$

In andere landen zijn meer gedetailleerde regels vanaf de jaren zestig tot wasdon gekomen. ${ }^{37}$ Ook op dit terrein heeft de OESO richtinggevende arbeid verricht. ${ }^{38}$

Een en ander neemt niet weg dat op deze materie nauwelijks vat kan worden gekregen. Artikel 9 Modelverdrag verwijst naar 'conditions ... which would have been made between independent enterprises', dat is de zogenaamde 'arm's length"-prijs. Blijkens punt 4 van de toelichting bij dit artikel laten de opstellers van het model de methode van prijscorrectie over aan het bilaterale overleg der staten.

De uitvoering van dit uitgangspunt is buitengewoon gecompliceerd, aangezien de veronderstelling die aan artikel 9 ten grondslag ligt, te weten de beschikbaarheid van een vergelijkbare transactie tussen onaflankelijke partijen, in veel gevallen niet opgaat.

In die gevallen dient men zijn toevlucht te nemen tot onrechtstreekse methoden van prijsbepaling. Naar Amerikaans recht pleegt hier te worden onderscheiden tussen methoden waarbij de prijs wordt bepaald uitgaande van de prijs die bij doorverkoop van het goed aan derden wordt verkregen, dan wel omgekeerd uitgaande van de kostprijs op het moment waatop de overdracht binnen concernverband plaatsvindt. ${ }^{39}$

Uit het proefschrift van Verdoner blijkt enerzijds dat ten aanzien van de hoofdzaken duidelijke parallellen kunnen worden waargenomen in de regelgeving wan de verschillende landen, doch anderzijds

Cursus Belastingrecht (Venmootschapsbelssting), onderdeel 2.12.C.

35. J. Verburg., Vewnootschapsbelasting, Fiscale hand- en studieboek en ar. A. Kluw er Deven= ter $1984, b \mid z, 150-151$.

36. Resolutie 25 april 1985 , BNB ro8 $9 / 196$.

37. Verdoner, a.w., biliz. 20.

38. Rapport 1979: Transfer pricing and Mulinational Errerprises, rapport 1984: Three taxation issues.

39. Zic aangaande deze materie: J.F. Spherdijk, Transfer pricing and multinational etitemprises; en Rapport wan de Commissie ter bestudering van de internationale winstallocaties; respectievelik Geschriften nr. 153 en 173 wan de Vereniging voor Belastingweterschap, Kluwer Deventer 198 . respectiewelijk 1987 . 
aventens hoe uiteenlopend de uitwerking is wanneer het op de details, en dus op het concrete geval, aankomt.

De problemen op dit terrein worden wel het best geillustreerd aan de hand van de deining die is ontstaan door de publikatie in 1988 van een rapport van het Amerikanse Treasury Department dat bekend staat als the White Paper. ${ }^{40}$ Dit rapport behelst een studie naar de uitwerking van een in 1986 in de wetgeving opgenomen bepaling volgens welke in geval van overdracht van onlichamelijke zaken tussen gelieerde personen, alan de overdragende partij winst moet worden toegerekend 'commensurate with the income' dat wit die zaak zelf voortvloeit. Dat leidt ertoe dat niet op de gebruikelijke wijze wordt getracht langs directe of indirecte weg tot de "arm's length'-prijs te geraken, doch dat zeer uitgebreide functionele analyses moeten worden gemaakt van de bedrijfsvoering van de gebruiker van het octrooi. Bovendien stipuleert het rapport dat de hoogte van de royalty in de loop der jaren kan worden aangepast wanneer het octrooi zeer winstgevend blijkt te zijn (superroyalty). Volgens het rapport is dit een regel die ook tussen onafhankelijke partijen gebruikelijk is. Om die reden zou een benadering als de onderhavige niet in strijd zijn met de internationaal gebruikelijke arm's lengthfilosofie.

In de wetenschappelijke commentaren wordt sterk betwijfeld of de visie van het Treasury Department strookt met de gangbare gedragslijn in het verdragenrecht. Integendeel, voor de belastingplichtigen worden niet alleen hoge kosten van het onderzoek ten behoeve van de Amerikaanse fiscus en moeizame discussies gevreesd doch ook het optreden van dubbele belasting, aangezien de wetgeving van andere landen het doorvoeren van corresponderende winstcorrecties niet zal toelaten. ${ }^{43}$

In het voorafgaande heb ik enige aandache besteed aan verdrags-

40. US Department of the Treastry and Internal Revenue Service, A Study of Interconpary Pricing, 18 October 1988.

4. Mark Penney, Internal Revenue Code Section 422 - The White Paper, European Taxation Fubruary 1989; Transfer Pricing for Intangibles: Special White Paper issue. Intertax 1989/2-3: Jon E. Bischel. The Sec.482 White Paper and Superroyalties. Existing and Proposed Transfer Pricing Methods, Bulletin for international fiscal documantation, Fobruary 1990. 
bepalingen betreffende vestigingsplaats, waste inrichting en intercompany-pricing. Bij elk van deze leerstukken bleek van interpretatieve moeilijkheden die een volledig uitbannen van dubbele belasting in de weg staan. Daarom ga ik thans in op het hiermee samenhangende, meer fundamentele wraagstuk van de verdragstoem passing door de rechter.

\section{Toepassing van belastingverdragen door de rechter}

De belastingplichtige die een beroep doet op de toepassing van een belastingverdrag, doet zulks in het kader van een hem door een nationale belastingdienst opgelegde aanslag. Een eventueel geschil betreflende uitlegging en toepassing van het verdrag wordt voorgelegd aan de rechter die in dat land tot oordelen bevoegd is. ${ }^{42} \mathrm{Bij}$ de uitlegging van de in het verdrag gebezigde woorden gaat de rechter in beginsel uit van het nationale recht. Niet alleen kan hij nauwelijks een andere keuze maken, bovendien gaat ook artikel $3 \$ 2$, OESOModelverdrag daarvan uit. ${ }^{43}$

Het is duidelijk dat zulks tot dubbele belasting dan wel lekken kan leiden ${ }^{44}$; Van Raad doet de interessante suggestie on als waste regel interpretatie naar het bronlandrecht aan te houden, maar geldend recht is dit vooralsnog niet. ${ }^{45}$ Nog etnstiger worden de problemen wanneer in een staat, anders dan in bij voorbeeld België, Nederland en (in beginsel) de Bondsrepubliek, niet de regel geldt dat het verdrag boven de wet gaat, ongeacht de vraag of de wet al dan niet van meer recente datum is dan het verdrag.

Het probleem is vooral bekend in de internationale relaties met de

42. Mits de rechter al ter zake van verdragstopassing kan worden geatliewd, vergehjk $\rfloor \mathrm{H}$. Christianse, Het problecm van cen internationale jurisdictie op belastingterrein, in: $\mathrm{Om}$ der schattinge wille (Van der Poelbundel), K.hwer Deventer $2 . j$, blz. 166.

43. De tukst van deze bepaling haide: "As regards the application of the Convention by a contracting State any term not defined therein shall, unless the context otherwise requires, bave the meaning which it has under the law of that State concerning the laxes to which the convention applies".

44. C. van Raad, Het nationale recht bij de vitlegging van belastingwerdragen, in: Van Wet naar recht (Scheltenbundel), Kluwer Deventer 198 外.

45. John Avery Jones, Interpretation of tax ireaties, Bulletin for international fiscal documenm ation $1986 / 2$. 
Verenigde Staten. Ik sprak reeds over the White Paper die een uitwerking is van de Tax Reform Act van 1986. Deze zou voor de handelspartners van de US niet zo'n probleem vormen, ware het niet dat in een wijzigingswet uit 1988 is bevestigd dat de US-verdragen en -nationale wetgeving van gelijke orde zijn en dat, in geval van conflict, het verdrag of de wet welke het jongst is, voorrang heeft. ${ }^{46}$

Een vlammend betoog van Helmut Becker en Felix Würm waarin deze gedragslijn als strijdig met de Weense Conventie betreffende het verdragenrecht aan de kaak wordt gesteld ${ }^{47}$, heeft niet mogen baten. Maar met Rosemarie Sanderson Schadé (t.a.p.) vraag ik mij wel af of de Verenigde Staten er verstandig aan doen zich zo onaantrekkelijk. te maken voor investcerders.

Nieuwe protocollen bij de verdragen van de Verenigde Staten met Belgie en Frankrijk geven inmiddels voedsel an de veronderstelling dat de Amerikanen niet rauwelijks willen overgaan tot 'treaty-overriding' doch wel dat zij de verdragspartners op krachtige wijze onder druk willen zetten tot verdragsherziening. ${ }^{48}$

Hoe dit ook zij, in veel gevallen zal de rechterlijke arbeid niet leiden tot een volledig tegengaan van dubbele belasting, en rijst de vraag of de belastingverdragen andere voorzieningen kennen om dit probleem op te lossen.

\section{Procédure amiable}

Het OESO-Modelverdrag kent in drie bepalingen een vorm van overleg tussen de fiscale autoriteiten der Staten met het doel bij de toepassing wan het verdrag opkomende fricties weg te nemen.

In artikel $4 \$ 2$ sub d verplicht het verdrag de Staten in onderlinge overeenstemming een oplossing te vinden ingeval de verdragsregels geen uitsluitsel verschaffen ten aanzien van de vraag in welk land een bepaalde natuurlijke persoon woont.

46. Rosentarie Sanderson Schade, Tax treaty overtides in we Technical and macellaneous revenue at of 1988 , Bulletin for international fiscal doctumentation $1989 / 5$.

47. Doublemation conventions and the comflet betwen international agreements and substequent domestic laws, Intertax $1988 / 8-9$.

48. Dianis J. Otmstead and Niels Dejean, Balgrum-US and France-US protocols highlighting US tax traty concerns, Bulletin for intermational fuscal documentation $1989 / \mathrm{s}$. 
Artikel $9 \$ 2$ - dat al eerder is genoend - heeft betrekking op de corresponderende winstcorrectie die in een land moet worden toegepast als consequentie van zodanige correctie in het andere land. Het verdrag stipuleert hier dat de bevoegde autoriteiten if necessary consult each other'. Deze bepaling is dus, anders dan de vorige, niet dwingend geformuleerd. En in beide gevallen heeft de belastingplichtige geen formele rechtsingang; het initiatief berust bij de fiscus.

Hetzelfde kan worden gezegd voor twee regelingen voor onderling overleg die zijn neergelegd in artikel $25 \$ 3$ Modelverdrag. Het betreft hier enerzijds problemen en interpretatie-werschillen die zijn gebleken bij de toepassing van het verdrag, alsmede de voorkoming van dubbele belasting in gevallen die niet zijn geregeld in het verdrag.

Anders is het gesteld met de regeling voor onderling overleg van artikel $25 \$$ I en 2 Modelverdrag (de mutual agreement procedure of procédure amiable). De belastingplichtige heeft het recht om binnen 3 jaar nadat hem is gebleken van belastingheffing die in strijd is met de bepalingen van de overeenkomst, die kwestie voor te leggen aan de bevoegde autoriteit van zijn woonstaat. De laatste zal, zo nodig in goed overleg met de bevoegde autoriteit van de andere stat, trachten een oplossing te bereiken.

Weliswaar geeft deze bepaling de belastingplichtige een rechtsingang, doch een afdwingbaar recht op een oplossing voor zijn probleem heeft hij niet ${ }^{49}$, en bij het overleg tussen de Staten is hij geen partij. Voorts wordt, in de praktijk meer dan in na te melden IFA-congresbundel (zie bij voorbeeld Schadé, t.a.p.), geklaagd over de lange duur van de procedure en de onzekerheid omtrent de uitkomst daarvan. Het aantal procedures is dan ook relatief gering. Het zou mij niet verbazen wanneer de belastingplichtigen alleen die gevallen voordragen warin zij de kans op succes op voorhand hoog inschatten.

Uit de bijdragen woor het IFA-congres van $198 \mathrm{r}$ over dit onderwerp blijkt dat een meerderheid voorstander is van versterking wan de positie van de belastingplichtige. Maar een minderheid keerde zich daartegen en ook overigens liepen de opvattingen over de aard 
van de te nemen maatregelen sterk unteen. ${ }^{50}$ Een wan de maatregelen waaraan men kan denken, is de overdracht van bevoegdheden aan een internationale belastingrechter. Zo schreef $\mathrm{P}$. VerLoren van Themaat in 1946 in zijn dissertatie: "Wenschelijk ware de instelling van een vast intemationaal gerechtshof voor de beoordeling van conflicten bij de toepassing van belastingverdragen en het (na uitputting van de nationale rechtsmiddelen) toekennen van een beroep op dit hof ook aan belastingplichtigen zelf. ${ }^{51}$ Christianse heeft in 1958 betoogd dat deze wens te hoog gegrepen is (t.a.p. blz. 180 e.v.). Hij bepleitte een college van arbiters gekozen uit de hoogste nationale rechtsprekende instanties (blz. Igo). Voor een international fiscaal gerechtshof werd de tijd ook in de jaren tachtig in elk geval nog niet rijp geacht. ${ }^{52}$

\section{Een belastingverdrag is een beperkt instrument}

Ik maak een tussenbalans op. De vraag of de totstandkoming en toepassing van de verdragen ter voorkoming van dubbele belasting hebben geleid tot volledige verwerkelijking van hun doel, heb ik aan de hand van enkele voorbeelden ontkennend beantwoord. Vervolgens bleek dat feilen een gevolg te zijn van het hanteren van een groot aantal vage normen alsmede het ontbreken van ten eerste een eenduidig interpretatiewoorschrift en ten tweede een rechterlijke instantie die de eenheid van uitlegging bewerkstelligt.

$\mathrm{Nu}$ vervullen belastingverdragen wel degelijk een zeer nuttige functie in het internationale verkeer, en nemen zij het overgrote deel van de dubbele druk weg. Maar de schaduwzijde wordt gevormd enerzijds door de resterende dubbele heffing, anderzijds door de velle kosten en moeite die de belastingplichtigen zich moeten getroosten om zowel de nationale wetten als de verdragen te beheersen en voor hen, in vaak moeizame onderhandelingen met de fiscale autoriteiten,

50. Karl Koch. Mutual agreenent-procedure and practice (Generalbericht), Cathiers de droit fiscal international, Volume LXVIa, Kluwer Dewenter 1981, 6la. 43 e.w.

51. International belastingretht, Uutg. H.J. Paris, Amaterdam ngato, ble. 201 .

32. Koch, a. w. ble. 47 " Wird die Shaftung einer Schiedsgerichesbarkeit oder eines internationalen Gerichtshofes in Steversachen seit langen gefordert, so diurfen doch die Widerstände gegen die Schaffung derartiger Institutionen heute noch zu gross sein." 
een bevredigende toepassing daarwan te bepleiten. Daarbij kont nog dat de contribuabelen in menig opzicht een zwakke rechtspositie innemen en niet zelden eieren voor hun geld kiezen door compromissen te sluiten.

Een bilateral verdrag ter voorkoming van dubbele belasting is dus naar zijn aard een beperkt instrument.

\section{De positie van het Europese bedrijfsleven}

Thans is het moment gekomen warop het wraagstuk wan de voorkoming van dubbele belasting in verband kan worden gebracht met het Europese bedrijfsleven.

Wanneer wij de positie van het Europese bedrijfsleven in ogenschouw nemen, dan gebeurt zulks in vergelijking met die van het Amerikaanse en Japanse bedrijfsleven. Wat daarbij in het oog springt, is dat de thuismarkt van elk bedrijf uit een Europees land aanzienlijk kleiner is dan die van een Amerikaans of Japans bedrijf. De marktomvang voor het Europese bedrijf verkeert in zijn voordeel zodra deze zich uitstrekt tot de gehele Gemeenschap van de Twaalf.

Maar aan de binnengrenzen van de Europese Gemeenschap bestaan nog steeds vele factoren die het vrije grensoverschrijdende ondernemen belemmeren, zodat er alle aanleiding bestaat op communautair niveau krachtige maatregelen te nemen om hierin verbetering te brengen. Ziedaar het concept van Europa 1992 waarover ik $U$ in algemene zin geen verdere uiteenzettingen hoef te geven.

Maar hoe is het gesteld met de belastingheffing in de Gemeenschap? Artikel 99 van het verdrag tot oprichting van de Europese Economische Gemeenschap. Trb. 1957, 9 r verplicht de angesloten landen tot harmonisatie van de wetgevingen inzake de omzetbelasting, de accijnzen en de andere indirecte belastingen. ${ }^{5}$ Op dit gebied is in de voorbije decennia zeer belangrijke vooruitgang geboekt door middel van de afschaffing van de interne dowanerechten, het gemeen-

5.3. Zie voor de stand wan zaken in de beginperiode S.C. H. Nederbungh, Wieuw fiscal recht

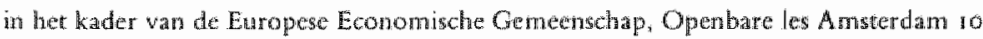
oktober 196r. Scheltema Holkema, Amsterdan 1903. 
schappelijke externe tarief, de instelling van de belasting over de toegevoegde warde en de uniforme grondslag daarvan. ${ }^{34}$ Verdere ontwikkelingen zijn hier nog te verwachten, doch zij maken geen deel uit van het onderwerp van deze voordracht.

Destand van zaken op het punt van de directe belastingen is volstrekt anders. In geen enkele bepaling van het oprichtingsverdrag van de EEG wordt uitdrukkelijk aandacht besteed aan harmonisatie op dit punt. Als gevolg daarvan heeft een Europees concern onder andere te maken met twalf verschillende stelsels wan belastingheffing, sterk uiteenlopende belastingtarieven ${ }^{55}$ en een veelheid van belastingfaciliteiten die bedrijven moeten prikkelen in een bepaald land te investeren. Kortom, nog afgezien van de problematiek wan de voorkoming van dubbele belastingheffing brengt de versnippering van het Europese grondgebied veel kosten met zich mee alsmede een fiscale verstoring van de efficiënte economische allocatie van produktiefactoren.

\section{Noodzaak van harmonisatie}

De laatste jaren wordt de roep om harmonisatie van de directe belastingen dan ook steeds luider. ${ }^{5 k}$ Toch bevat ook de Europese Akte van 17 februari $1986^{57}$ nog geen concrete voomemens dienaangaande. Wel werd een afzonderlijk 'White Paper on direct tax

54. De literatueir dienangaande is overstelpend. Ik wolsta met te verwijzen naar Sibren Chossen, Tax strucure developments, in: Tax coordination in the Europeari Com-

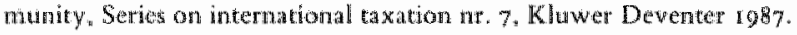

35. Richard M Burd, Corporate-personal ax integration en Julian S. Alworth, Taxation and the cost of capial: a comparison of six $\mathbb{E C}$ comtries; beide in: Tax coordination in the European Community, Series on international taxation $\mathrm{nr}$. 7. Kluwer Dewenter $4.98 \%$

56. Ziv voor een all wat oudere momentopname Th. W. Vogelaar, De stand der belasting hatmonisatie, Geschiften van de Vereniging voor Belastingwetemachap nr. 126, Kluwer Dewenter 1970. Vijf jas later verkeer het Europese integratestreven echter in het slop: aldus I. Verburg, Vennootschapbelasting, in: Fiscale harmonisatie ito de EG, Serie Europese Monografietn, Kluwer Deventer 1975 .

\$7. Trb. 1986 nr. 63; vergelijk tevens Trb. 1987 nr. 118. 
harmonisation" in het wooruiczicht gesteld ${ }^{53}$ maar naar verluidt mogen wij zulks vooralsnog niet tegemoet zien. ${ }^{59}$

Musgrave meent:...it may be said that the major remaming problem of tax coordination to be faced by the Community is that of company tax harmonisation". Deze zou gestalte moeten krijgen door achtereenvolgens tarieven en heffingsgrondslag gelijk te trekken, terwijl bovendien aandacht moet worden besteed aan de wijze waarop de heffingsgrondslag over de landen wordt verdeeld.

Vanuit het bedrijfsleven is ten overstatan van het Europese Parlement gepleit voor:

I. afschaffing van aanvullende directe heffingen naast de normale winstbelasting (zoals de Duitse Gewerbesteuer).

2. internationale neutraliteit in geval van verrekening van vennootschapsbelasting met inkomstenbelasting en

3. harmonisatie van tarieven. ${ }^{60}$

Nooteboom bepleitte onlangs actie op vier punten:

1. eliminatie van nationale bepalingen die fiscale discriminatie inhouden,

2. harmonisatie van de heffingsgrondslagen in de winstbelasting,

3. het wegnemen van belemmeringen voor belastingplichtigen gevestigd in verschillende lidstaten om een gezamenlijke onderneming te beginnen, en

4. bevordering van een regeling voor verplichte arbitrage."

McLure meent dat Europa er goed aan zou doen het Amerikanse systeem van unitary taxation te omarmen. ${ }^{62}$ Bij toenemend grensoverschrijdend verkeer is het arm's length beginsel van verdeling van de heffingsgrondslag niet vol te houden en is een verdeelsleutel op basis van loonkosten, vermogen en onzet beter hanteerbalar. Mijns inziens zijn de voorstellen van McLure het overwegen waard, doch

58. Servas van Thiel, The Single Act and tax harmonisation in the European Comenunities, European Taxation 198798 , blz. 240

59. Coopers Lybrand, Tax harmonisation and 1992 in the Eutopean Conmunity, Financial Times Business Information, preserited to the IFA-congress, Ansteddam 1988, bli. 72

60. J.A. van der Bijl, Het Europese bedrijfsleven en de Cockfeld-yoorstellen, Maandblad Belastingbeschouwingen nr. 9 , september 1988 .

61. A. Nooteboom, Vier belangrijke elementen bij directe belastingen in de Europese Gemeenschappen en 1992, SEW 10 (ng88) ok tober.

62. T.a.p. (zie noot 23). Cnossen wolkt hem daarin, zie ESE 6 december 1989 blz. 4207 . 
zorgvuldig zal moeten worden onderzocht of unitary taxation inderdaad in technische zin superieur is a an toepassing van het arm"s length-concept. Bovendien vergen die voorstellen instelling van éen Europese belastingwet en een centrale dienst die de fiscale winsten bepaalt en aan de landen toerekent. Het komt mij voor dat deze maatregelen niet alleen in technische zin zeer veel voeten in de aarde zullen hebben, doch dat een zo ver galand politiek commitment vooralsnog binnen de Gemeenschap niet kan worden gevonden.

Deze bezwaren gelden ook voor het voorstel van VerLoren van Themaat voor een separate Europese vennootschapsbelasting waaronder slechts de grootste Europese concerns zouden worden gebracht. ${ }^{63} \mathrm{lk}$ vrees hiervan bovendien problemen omdat cen concern wellicht niet elk jaar voldoet aan de eisen van die heffing, dan wel opzettelijk zal trachten nu eens wel dan weer niet geheel of gedeeltelijk onder de nationale dan wel onder de Europese vennootschapsbelasting te vallen.

\section{Initiatieven van de Europese Commissie}

De Europese Commissie heeft een aantal voorstellen voor richtlijnen gedaan die (nog) niet tot Richtlijn zijn verheven. Ik som de voorstellen die verband houden met de heffing van winstbelasting op:

- Gemeenschappelijke fiscale regeling voor fusies, splitsingen en inbreng van activa met betrekking tot wennootschappen uit verschillende lid-staten (ingediend I6 januari I969);

- Gemeenschappelijke fiscale regeling voor moedermaatschappijen en dochterondernemingen uit verschillende lid-staten (ingediend 16 januari 1969);

- Harmonisatie van de stelsels van vennootschapsbelasting en van de bronheffingen op dividenden (ingediend 1 augustus 1975; intrekking inmiddels aangekondigd); ${ }^{64}$

63. P. Vartoren wan Themat, Europese wennootschapsbelasting hulpmiddel bij integratie, en Schets van cen EG-Vennootschapsbelasting, Financied Dagblad 27 en 28 januari 1988 . Zie voor enige andere kritische noten het verslag van een congres door P.HJ. Essers, Europese Vennootschapsbelasting. TVVS rggo no. 903.

64. Persbericht nr. P-22 d.d. 18 april 1990 wan de Europese Commissie. Fiscafax 263. 
- Toepassing op beleggingsinstellingen van de vorige richtlijn (ingediend 24 juli 1978 );

- Voorkoming van dubbele belasting in geval van winstcorrecties tussen verbonden ondernemingen (scheidsrechterlyjke procedure; ingediend 29 november 1976 );

- Harmonisatie van regels betreffende verliesverrekening (ingediend 6 september 1984$)$;

- Gemeenschappelijk stellsel van bronheffing op rente (ingediend ro Cebruari 1989$)^{55}$

Inmiddels is bovendien een voorontwerp voor een richtlijn betreffende de harmonisatie van de regels betreffende de fiscale winstbepaling opgesteld. ${ }^{66}$

Ik kan deze voorstellen hier niet bespreken. Waar het nu om gaat, is dat uit dit overzicht blijkt dat de Europese Commissie weliswalar veel initiatieven ontplooit die strekken tot harmonisatie van de directe belastingen zelf, doch dat de voorkoming van dubbele belasting minder nadruk krijgt. Uiteraard kan de harmonisatie van heffingsgrondslagen reeds een aantal fricties wegnemen welke thans bestaan bij de toepassing van de verdragen. ${ }^{67}$

Doch het enige voorstel dat rechtstreeks betrekking heeft op de voorkoming van dubbele belasting, is dat betreffende een scheidsrechterlijke procedure. Het voorstel komt erop neer dat de belastingplichtige eerst de procédure amiable moet volgen, en dat bij uitblijven van succes daarvan de zaak wordt voorgelegd aan een college van arbiters. Alhoewel op deze wijze de moeilijkheden bij de verdragstoepassing niet principieel worden bestreden, zal in een groter

65. Alle opgenomen in Nederlandse regelingen van internationaal belastingreche, dect III.H. Zie voors Coopers \& Lybrand, aw. Norbere Andel. Determination of Company profits, in: Tax coordination in the European Contuminity, Series on international taxation nr. 7, Kluwer Deventer 1987 .

66. John Goldsworth, Special supplement Tax Planning International Review, June 1988 ; Willem G. Kuiper, European Taxation, October 1988.

67. Me: Cnossen (onder andere تiscaal beleid in de Europese Gemeenschap, Pre-adwies voor de Koninklike Vereniging woor de Stathuishoudkunde 1988 , Stenfert Kroesc. Leiden I98) acht ik vooralnog volledige harmonisatie niet noodzakelijk. Het belastingniveau weerspiegelt atch in het niveat van juridische, technitche en sociale infrastructurur en is als zodanig bij de allocatie van produktiefactoren well en bepalnde matur niet een verstorende factor. 
aantal gevallen dan thans een oplossing worden gevonden. Zeer belangrijke nadelen van de regeling bestaan in de lange tijdsduur die met de behandeling van een klacht is gemoeid, en de onrechtstreekse betrokkenheid van de belastingplichtige daarbij. ${ }^{68}$

\section{Voorkoming van dubbele belasting in de Europese Gemeenschap}

Alle voorstellen laten onaangetast de thans bestaande situatie dat een concern met vestigingen in alle 12 lidstaten van de EG moet onderhandelen met 12 verschillende belastingdiensten over 66 bilaterale verdragen!

Artikel 220 EEG Oprichtingsverdrag luidt:

'De Lid-Staten treden, voor zover nodig, met elkaar in onderhandeling ter verzekering, voor hun onderdanen, van (...)

- de afschaffing van dubbele belasting binnen de Gemeenschap, (...).'

Nu kan men zich op het standpunt stellen dat aan dit voorschrift is voldaan door het sluiten van verdragen door alle leden met alle andere leden. Doch in deze voordracht heb ik U duidelijk gemaakt dat daarmede niet alle problemen tot een goed einde zijn gebracht. Ik siluit mij dan ook aan bij Wingert wanneer hij opmerkt: 'Auf dem Gebiete der internationalen direkten Besteuerung gebührt einer wirksamen Vermeidung der Doppelbesteuerung die höchste Priorität: ${ }^{69}$

Reeds in 1982 hebben Chown en Hopper gepleit voor een multilateraal belastingverdrag in de Europese Gemeenschap. Zo ver is het

68. K. Riks, Het woorstel woor een richtlijn inzake voorkoming van dubbele belasting in geval wan winstcorrecties tussen verbonden ondermemingen (scheidsrechterlijke procedure), in: Fiscale Miniaturen, FED Deventer 1978. De Nederlandse regering heeft een voorkeur uitgesproken voor en nultilateral werdrag boven arbitrage, zine WFR 1979 bौlz. 438 .

69. Karl-Dieter Wingert, Der Stand der EG-Steuerharmonisierung. Hefte zur Intemationalen Besteuerting, Heft 35, Universität Harnburg 1987, blz. 26 
echter niet gekomen. Toch bestaat er binnen het Europese Parlement aandacht voor het onderhavige wraagstuk getuige een schriftelijke vraag van het lid André Fourçans aan de Commissie van de Europese Gemeenschappen (tekst overgenomen uit Vakstudie-Nieuws 22 maart 1990, blz. 892-893):

\section{'Betreft: Belastingovereenkomsten en Europese concens:}

De grensoverschrijdende fiscale overeerkomsten tussen de diverse Lid-Staten vertonen verschillen. In totaal zijn het 66 onderscheiden overeenkomsten. Bijgevolg worden op de dochtermatschappijen van concerns in de diverse Lid-Staten dat wil zeggen vanaf de grens andere belastingwetten toegepast. Welke maatregelen denkt de Commissie te nemen ten aanzien van de belastingheffing op concerns met inbegrip van hun Europese dochterondernemingen, naast de reeds bestaande maatregelen, teneinde de vorming van grote Europese concerns tegenover de Amerikaanse en Japanse ondernemingen te bevorderen?

\section{Antwoord van mevrouw Scrivener namens de Commisite:}

De Commissie heeft voorstellen gedaan die van bijzonder belang zijn voor de belastingwetgeving voor concerns.

In de eerste plaats wordt met het voorstel voor een richtlijn "moeder-en dochterondernemingen", ${ }^{70}$ dat deel uitmaakt van een pakket van drie richtlijnen betreffende de transnationale samenwerking tussen Europese ondernemingen, beoogd een einde te maken aan de dubbele belastingheffing op dividenden die door een in een Lid-Staat gevestigde dochteronderneming worden uitgekeerd aan haar in een andere Lid-Staat gevestigde moederonderneming, door de inhouding aan de bron op deze dividenden af te schaffen.

Daarnaast is het volgens het ontwerp van statuut van de Europese vennootschap ${ }^{7 /}$ mogelijk de winst van de Europese vennootschap te compenseren met het verlies van hat in andere Lid-Staten gevestigde vaste inrichtingen en wan har buitenlandse dochterondernemingen."

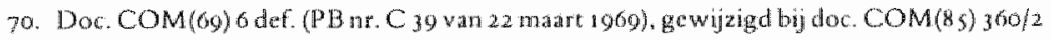
cteff.

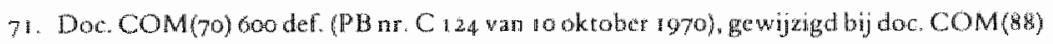
$1.90 \mathrm{~d}$ 


\section{Voorstel}

Uit dit antwoord blijkt dat de Europese Commissie vooralsnog de verdragenproblematiek wil laten rusten. ${ }^{72}$ Mijns inziens echter vergt het belang wan een soepele werking van de interne markt dat dat vraagstuk op korte termijn uit de onderste lade wordt gehaald.

Mij dunkt dat matregelen moeten worden genomen teneinde te bewerkstelligen dat de Europese ingezetenen binnen de grenzen van de gemeenschap niet langer worden geconfronteerd met de hierboven geschilderde moeilijkheden ter zake van de toepassing van 66 bilaterale verdragen en dat hen een juridisch afdwingbaar recht wordt toegekend op voorkoming van dubbele belasting. Ik wil niet zo ver gaan dit recht tot mensenrecht te verheffen, maar voor zover her gaat om de interne verhoudingen binnen een groep nauw samenwerkende staten dunkt mij dit wel een zaak die vanzelfsprekend zou moeten zijn.

De realisatie van dit alles zou de worm kumnen krijgen van een multilateraal verdrag. ${ }^{73}$ Doch evenzeer en wellicht nog beter dunkt mij mogelijk de regels betreffende de buitenlandse belastingplicht van niet-ingezetenen alsmede die betreffende de eenzijdige terugtred van staten waar het betreft baten van hun ingezetenen uit andere EG-landen, bij Richtlijn op elkaar af te stemmen en te harmoniseren. In dat geval kunnen alle onderlinge belastingyerdragen worden afgeschaft! Deze exercitie zou min of meer erop neerkomen dat binnen de EG het beginsel van de heffing naar de wereldwinst zou worden verlaten.

In beide opties komt binnen de EG eenduidige regelgeving op thet stuk van het internationale belastingrecht tot stand die in beginsel wordt toegepast en uitgelegd door de bestaande nationale belastingdiensten en rechters, maar waarbij eenheid van rechtspraak via artikel 177 EG-Verdrag wordt gewaarborgd door het Europese Hof van Justitie. ${ }^{74}$

72. Fin incieel Dagblad 30 januari 1990 meldo dat de Commissie eerdaags zal vootstellen drie Richelijnen wast te stellen, namelijk betrefende moeder-dodher-werhoudingen, arbitrage en fusies.

73. In EG-verband is hieran wel degelijk gedacht (zic Hamackers, Bulletin 1986 blz. 99 e. $\%$ ). Een multilateral verdrag late echer de grensproblematiek in begingel in stand.

74. Zie dienangaande B.H. ter Kuile, Hoe ver ligt Den Haag nog van Brussel?, Plein-lezing, Wolters Kluwer Recheswetenschappen 1989 . 
Aan het einde van mijn rede gekomen, wil ik de leden van het College van Bestuur en de overige personen die hebben meegewerkt aan mijn benoeming tot hoogleraar in het Belastingrecht aan de Rijksuniversiteit Limburg danken voor het in mij gestelde vertrouwen.

In mijn loopbaan heb ik het voorrecht gehad telkens te worden begeleid door voortreffelijke juristen.

Als belastingadviseur in Rotterdam heb ik onder de inspirerende leiding van Theo Zeegers kunnen kennis maken met het belastingrecht in de praktijk. Zonder kennis daarvan hebben fiscaal-wetenschappelijke bespiegelingen in de regel weinig betekenis.

Daarna heb ik een aantal jaren met veel genoegen mogen werken in de Leidse vakgroep Belastingrecht. Ik heb daar met eenieder uitstekend kunnen samenwerken. Voor mijn wetenschappelijke ontwikkeling ben ik de meeste dank verschuldigd aan Jan Verburg en Jan Giele. Aan de wekelijkse indringende discussies met Jan Verburg over - meestal - vennootschapsbelasting denk ik met veel genoegen terug. En Jan Giele heeft mij als promotor precies die steun en tegelijkertijd ook die vrijheid gegeven die ik nodig had om de klus op mijn manier te klaren.

Een fantastische ervaring was het werk als waarnemende griffier van de Belastingkamer van de Hoge Raad. Ik heb in die tijd ontzettend veel geleerd, en voor de wijze waarop ik bij de Kamer heb kunnen functioneren, ben ik de vice-president mr. L. van Dijk zeer erkentelijk. Een bijzondere herinnering bewaar ik ten slotte aan de tijd dat ik de medewerker van Jan van Soest was. Ik heb een beetje kunnen opsteken van zijn overweldigende kennis van het Recht in het algemeen en het Belastingrecht in het bijzonder, maar ik weet mij sedertdien eens te meer ook nimmer volleerd.

Aan de Faculteit der Rechtsgeleerdheid te Maastricht is het goed toeven. De collegiale verhoudingen zowel bimnen de vakgroep Publiekrecht als daarbuiten zijn prima, en ik heb dan ook de beste 
verwachtingen ten aanzien van de wijze waarop wijgezamenlijk de tweede studierichting van de Faculteit ter hand zullen nemen.

Veel stel ik mij ook voor van de samenwerking met de collega's van de Faculteit der Economische Wetenschappen met wie zeer goede relaties worden onderhouden. Het is trouwens Jan van de Poel gewcest die de fundamenten voor de fiscale studierichting in Maastricht heeft gelegd.

Mijn streven zal erop zijn gericht in onderwijs en onderzoek van het belastingrecht een naw samenhang tussen wetenschap en praktijk tot stand te brengen.

De studenten hoop ik te leren een evenwicht te vinden tussen de gerechtwaardigde belangen van enerzijds de belasting heffende gemeenschap en anderzijds het belasting betallende individu.

lk heb gezegd. 